Pengaruh Latihan SKJ 2012 terhadap Kebugaran....(Arisman)

\title{
PENGARUH LATIHAN SKJ 2012 TERHADAP KEBUGARAN JASMANI SISWA SMP NEGERI 35 PALEMBANG
}

\author{
Oleh: Arisman \\ (Dosen Universitas PGRI Palembang) \\ Email : arisman@gmail.com
}

\begin{abstract}
Abstrak
Penelitian ini berawal dari rendahnya kebugaran jasmani siswa di sekolah. Hal ini terlihat pada pembelajaran penjasorkes yang dilakukan di lapangan. Rendahnya kemampuan siswa dalam melakukan aktifitas fisik di lapangan terlihat dari kemampuan siswa dalam belajar mereka sulit konsentrasi, cepat bosan dan mudah mengantuk, sehingga pembelajaran yang dilakukan belum berjalan sebagaimana yang diharapkan. Tujuan dari penelitian ini adalah untuk mengetahui peningkatan kebugaran jasmani siswa di sekolah dengan menggunakan latihan SKJ 2012. Subyek penelitian adalah siswa Sekolah Menengah Pertama Negeri 35 Palembang yang berjumlah 70 orang. Jenis penelitian yang digunakan adalah penelitian eksperimen. Penelitian ini menggunakan pendekatan kuantitatif. Data diperoleh dalam bentuk kuantitatif yaitu melalui hasil kebugaran jasmani dengan tes TKJI. Hasil analisis data menunjukkan bahwa didapat $t_{\text {hitung }} 13,85>t_{\text {tabel }} 1,676$, berarti signifikan. Jadi, latihan SKJ 2012 memberikan pengaruh terhadap peningkatan kebugaran jasmani siswa SMP 35 Palembang.
\end{abstract}

Kata Kunci : SKJ 2012, Kebugaran Jasmani

\section{THE EFFECTIVENESS OF SKJ 2012 EXERCISE TOWARDS STUDENTS' PHYSICAL FITNESS IN SMP NEGERI 35 PALEMBANG}

\begin{abstract}
This study originated from the low physical fitness of students in school. This is seen in learning penjasorkes conducted in the field. The low ability of students in doing physical activity in the field seen from the ability of students in their study difficult to concentrate, quickly bored and easy to drowsy, so that learning has not run as expected. The purpose of this research is to know the improvement of physical fitness of students in school by using SKJ 2012 exercises. Research subjects are students of Palembang State Junior High School 35 which amounts to 70 people. The type of research used is experimental research. This study uses a quantitative approach. Data obtained in the form of quantitative that is through the result of physical fitness with TKJI test. The result of data analysis shows that tcount 13,85>ttable 1,676, meaning significant. So, SKJ 2012 exercises have an effect on the physical fitness improvement of SMP 35 Palembang students.
\end{abstract}


Keywords: SKJ 2012, Physical Fitness

\section{A. PENDAHULUAN}

Pendidikan jasmani dan olahraga merupakan Modal yang paling utama dan penting dalam mendidik dan mengembangkan sumber daya manusia sebagai bagian yang mendasar. Olahraga merupakan satu-satunya kegiatan yang mampu menyatukan semua elemen masyarakat tanpa memandang suku, ras maupun agama. Sehingga tak seorang pun di dunia ini yang tidak menyukai kegiatan olahraga. Mulai dari rakyat jelata hingga para pejabat serta pemimpin Negara. Hal ini terjadi karena satu tujuan yaitu menciptakan tubuh yang kuat dan jiwa yang sehat (Hermansah, 2018:36).

Hasil yang diharapkan itu akan dapat dicapai apabila kegiatan olahraga yang dilaksanakan berkesinambungan, terencana, terprogram, konsekuen, dan menuntut kerja keras agar tercapai budaya olahraga, guna meningkatkan kualitas manusia Indonesia. Hal ini tercantum dalam undang-undang nomor 3 Tahun 2005 mengatur tentang penyelenggaraan dan pelaku olahraga di Indonesia. Oleh karena itu dalam pembinaan olahraga dibutuhkan kesabaran, keikhlasan, dan pengorbanan sebagai upaya melaksanakan pendidikan jasmani dan olahraga di lembaga formal. Proses pembentukan sikap dan pembangkitan motivasi harus di mulai pada usia dini.

Tenaga pengajar dalam pendidikan jasmani diharapkan memiliki, keterampilan serta pengetahuan yang luas untuk memberikan pengalaman yang bagus kepada peserta didik untuk mencapai suatu keberhasilan dalam mendidik peserta didik. Penguasaan suatu metode mengajar bagi seseorang guru sangat penting dalam meningkatkan hasil dalam pembelajaran olahraga. Keberhasilan guru dalam mengajar akan membawa dampak positif terhadap prestasi yang diinginkan. Untuk meraih prestasi yang tinggi perlu dilaksanakan berbagai langkah antara lain: dengan meningkatkan metode belajar dan latihan serta 
Pengaruh Latihan SKJ 2012 terhadap Kebugaran....(Arisman)

memperbaiki sarana dan prasarana. Faktor lain yang berpengaruh atas prestasi dalam pembelajaran olahraga adalah tingkat kebugaran seseorang, oleh karena itu pemerintah sudah sejak dulu berperan aktif dalam membentuk manusia Indonesia yang sehat baik jasmani maupun rohaninya, hal ini dapat dilihat dari upaya pemerintah mewujudkan Visi Indonesia bugar 2020 dengan senam.

Senam sangat diperlukan dalam mewujudkan peserta didik ke arah yang lebih baik dalam memperoleh kebugaran jasmani. Hal ini penting dalam meningkatan kualitas diri khususnya kepada siswa itu sendiri, yang mana hasil dari kebugaran itu sudah dapat diarahkan ke dalam dimensi positif yang berguna untuk menunjang hasil belajar siswa di sekolah. untuk memperoleh kebugaran tersebut harus melibatkan semua elemen dalam lingkungan sekolah. Sekolah harus mempersiapkan semua perangkat untuk menunjang para siswa menuju sehat dan bugar seutuhnya misalnya senam.

Senam merupakan aktivitas gerak tubuh yang efektif dalam mengoptimalkan pertumbuhan dan perkembangan peserta didik. Gerakan-gerakan senam sangat sesuai untuk mengisi program pendidikan jasmani seperti kekuatan, daya tahan otot dari seluruh bagian tubuh. Di samping itu senam juga berpotensi mengembangkan keterampilan gerak dasar, dan juga sebagai alat untuk mengukur tingkat kesehatan dan kesegaran peserta didik. Lebih penting lagi senam dapat meningkatkan kebugaran bagi siapapun yang melakukannya, meskipun harus mengulang suatu gerakan senam tertentu berpuluh kali.

Dukungan Pemerintah sudah mulai pada masa orde baru. Pada waktu itu pemerintah telah mempersiapkan pembentukan program peningkatan pelayanan kesehatan masyarakat lewat peningkatan kinerja di puskesmas, peningkatan gizi lewat posyandu serta tak lupa mengajak mengajak masyarakat untuk gemar berolahraga dengan memperkenalkan senam kesegaran jasmani (SKJ). Senam kesegaran jasmani terus berkembang sehingga sekarang ini senam kesegaran jasmani ini terus berinovasi dari awal SKJ'84 hingga sekarang yang kita ketahui. Senam merupakan olahraga yang dapat dilakukan secara masal, mulai dari tingkat 
dasar, menengah, atas dan masyarakat umum. Hasil observasi yang dilakukan penulis di SMP Negeri 35 Palembang pun mengalami pergeseran, ini dapat dilihat dari kecenderungan yang ada pada siswa putra cenderung lebih malas untuk melakukan senam, siswa putra lebih menyukai olahraga yang sifatnya games seperti, sepakbola dan bolavoli, sedangkan senam cenderung dilakukan siswa laki-laki hanya pada saat pagi jum'at karena kewajiban dari sekolah untuk melaksanakan senam pagi (Dari hasil wawancara yang dilakukan dengan guru olahraga SMP Negeri 35 Palembang). Rendahnya kebugaran jasmani siswa di sekolah terlihat pada pembelajaran penjasorkes yang dilakukan di lapangan. Dalam hal ini kemampuan siswa dalam melakukan aktifitas fisik di lapangan terlihat lemah terkesan tidak semangat dalam belajar mereka sulit konsentrasi, cepat bosan dan mudah mengantuk, sehingga pembelajaran yang dilakukan belum berjalan sebagaimana yang diharapkan.

Dari uraian di atas dapat disimpulkan bahwa senam kesegaran jasmani merupakan aktifitas yang efektif untuk mengoptimalkan pertumbuhan dan perkembangan peserta didik. Di samping itu juga berpotensi mengembangkan keterampilan gerak dasar kemudian juga bisa meningkatkan kebugaran jasmani secara efektif bagi siapa saja yang melakukannya. Persoalannya adalah bagaimana senam dapat dimanfaatkan secara optimal oleh semua elemen di sekolah untuk mencapai tujuan pendidikan. Apa lagi dengan adanya bermacam-macam jenis senam yang sudah banyak tersedia saat ini.

Senam merupakan rangkaian latihan tubuh yang diciptakan dengan berencana, disusun secara sistematis dengan tujuan membentuk dan mengembangkan karakter individu secara harmonis (Margono, 2009:17)

Senam meskipun sudah lama dikenal di Indonesia, tetapi pengenalan secara menyeluruh baru dimulai sekitar tahun tujuh puluhan, dengan diperkenalkannya senam pagi Indonesia. Senam ini dikemas secara indah dan pelaksanaanya diiringi musik, kemudian baru banyak bermunculan senam-senam yang lain salah satunya 
Pengaruh Latihan SKJ 2012 terhadap Kebugaran....(Arisman)

adalah senam kesegaran jasmani (SKJ'84) yang terus berinovasi sampai saat ini yang dikenal dengan SKJ 2012. Manfaat senam menurut Margono (2009:21)

1. Untuk dapat memberikan ransangan yang diperlukan bagi pertumbuhan badan.

2. Untuk mengembangkan cara bersikap dan bergerak dengan sewajarnya.

3. Untuk memperbaiki dan mencegah pengaruh buruk di sekolah misalnya duduk dibangku terlalu lama.

4. Untuk mempertebal rasa kebanggaan (dalam perlombaan-perlombaan antar bangsa).

5. memupuk keberanian dan kepercayaan diri.

6. meningkatkan rasa tanggung jawab terhadap kesehatan diri dan lingkungan.

7. Memupuk kesanggupan untuk bekerjasama, misalnya dalam melakukan latihan harus saling membantu.

Menururt pendapat Brick manfaat dari melakukan olahraga senam adalah sebagai berikut:

1. Jantung

Menurut Brick (2001:4-5) dengan oksigen selama bergerak, otot membutuhkan oksigen untuk bekerja. Ketika beban otot meningkat, tubuh menanggapi dengan meningkatkan jumlah oksigen yang di kirim ke plosokplosok otot-otot dari jantung. Detak jantung dan frekuensi pernapasan meningkatkan sampai memenuhi kebutuhan tubuh. Oksigen di ubah menjadi karbondioksida, yang di hembuskan sehingga tubuh berkeringat.

2. Kekuatan otot

Otot harus di latih melebihi normalnya. Hal ini disebut prinsip beban lebih untuk memperkuat otot, dan melatih intensitas yang tinggi dalam waktu yang singkat, mempergunakan tenaga yang maksimum dan di ulang-ulang (Brick, 2001:5).

3. Daya tahan otot

Otot merupakan salah satu alat yang digunakan untuk menggerakan anggota tubuh, sebagai daya penggerak aktivitas fisik diperlukan otot yang kuat, kekuatan 
otot juga dapat melindungi seseorang dari cidera saat beraktifitas gerak seharihari. (Brick, 2001:5-6).

4. Kelenturan

Kelenturan adalah gerakan yang berada di sekeliling sendi. Seperti peregangan akan membantu meningkatkan kelenturan dan sirkulasi darah kembali ke jantung. Otot sifatnya seperti pita karet semangkin kuat anda semangkin elastis karet itu. (Brick, 2001:6).

5. Komposisi tubuh

Komposisi tubuh, yang menunjukan perbandingan kumpulan otot, tulang, dan cairan-cairan penting didalam tubuh yang dibandingkan dengan lemak. (Brick, 2001:6). Kebugaran jasmani merupakan kesanggupan dan kemampuan tubuh dalam melakukan penyesuaian (adaptasi) terdapat pembebasan fisik yang diberikan kepadanya tanpa menimbulkan kelelahan yang berlebihan (Wiarto, 2015:55). Tubuh yang bugar sangat penting dalam menjaga aktifitas kehidupan sehari-hari serta terhindar dari berbagai penyakit. Namun, nilai kebugaran jasmani setiap orang berbeda sesuai dengan tugas tuntutan fisik masing-masing. Kebugaran jasmani adalah komponen yang dikelompokkan dengan kesehatan (Health Realated PhysicalFitness) dan kelompok yang berhubungan dengan keterampilan (Skill Related Physical Fitness) (Wiarto, 2015:56).

Komponen yang berkaitan dengan kesehatan terdiri dari daya tahan jantung, paru-paru, komposisi tubuh, fleksibilitas, kekuatan dan daya tahan otot (muscular). Sedangkan komponen Kesegaran Jasmani yang berhubungan dengan keterampilan, yaitu power, kecepatan, kelincahan, koordinasi gerak, kecepatan reaksi dan keseimbangan. Untuk menjalankan aktifitas sehari-hari.

Komponen-komponen kebugaran jasmani menurut Wiarto (2015:56-58):

1. Komposisi tubuh

komposisi tubuh adalah persentase (\%) lemak dari berat badan total dan Indeks Masa Tubuh (IMT). Komposisi tubuh dapat di ukur dengan, skinfold alipers, IMT. 
Pengaruh Latihan SKJ 2012 terhadap Kebugaran....(Arisman)

2. Kelenturan atau fleksibilitas tubuh

Kelentukan adalah luas bidang gerak yang maksimal pada persendian, tanpa dipengaruhi oleh suatu paksaan atau tekanan.

\section{Kelincahan}

merupakan kemampuan seseorang untuk dapat mengubah arah dengan cepat dan tepat pada waktu bergerak tanpa kehilangan keseimbangan.

4. Kekuatan otot

merupakan kontraksi maksimal yang dihasilkan otot, untuk membangkitkan tegangan terhadap suatu tahanan.

5. Daya tahan jantung paru

Kemampuan jantung, paru dan pembuluh darah berfungsi secara optimal dalam mengambil O2 secara maksimal (VO2 maks) dan menyalurkan keseluruh tubuh terutama jaringan aktif sehingga dapat digunkan dalam proses metabolisme dalam tubuh.

6. Kecepatan

Kecepatan adalah kemampuan untuk menempuh jarak tertentu dalam waktu yang seminimal mungkin.

7. Daya tahan otot

Daya taha otot merupakan kemampuan untuk kontraksi submaksimal secara berulang-ulang atau atau berkontraksi terus menerus dalam waktu tertentu. orang yang memiliki kesegaran jasmani adalah orang yang mampu menyelesaikan pekerjaan sehari-hari tanpa mengalami hambatan fisik yang berarti di samping itu dia masih mampu 'melaksanakan pekerjaan yang lain yang bersifat rekreasi.

Dalam kesegaran jasmani terdapat kompone-komponen yang dibagi dalam tiga kelompok yaitu (Harsuki, 2003:273-274): 
1. Kesegaran jasmani yang berhubungan dengan kesehatan yaitu:

a. Daya tahan kardiovaskuler

Komponen ini menggambarkan kemampuan dan kesanggupan melakukan kerja dalam keadaan aerob, artinya kemampuan dan kesanggupan sistem peredaran darah pernapasan, mengambil dan menyediakan oksigen yang dibutuhkan.

b. Kekuatan otot

Kekuatan otot banyak diperlukan dalam kehidupan sehari-hari, terutama untuk tungkai dan yang harus menahan berat badan.

c. Daya tahan otot

Daya tahan otot adalah kemampuan dan kesanggupan otot untuk kerja berulang-ulang tanpa mengalami kelelahan.

d. Fleksibilitas

Kemampuan gerak maksimal suatu persendian.

e. Komposisi tubuh

Berhubungan dengan pendistribusian otot dan lemak diseluruh tubuh dan pengukuran komposisi tubuh

2. Kesegaran jasmani yang berhubungan dengan keterampilan motorik

a. Keseimbangan

Keseimbangan adalah berhubungan dengan sikap mempertahahankan keadaan keseimbangan (equilibrium) ketika sedang diam atau sedang bergerak.

b. Daya Ledak

Daya ledak adalah berhubungan dengan laju ketika seorang melakukan kegiatan, atau daya ledak merupakan hasil dari daya $\mathrm{x}$ percepatan (force $\mathrm{x}$ velocity).

c. Kecepatan 
Pengaruh Latihan SKJ 2012 terhadap Kebugaran....(Arisman)

Kecepatan adalah berhubungan dengan kemampuan untuk melakukakn gerakan dalam waktu yang singkat.

d. Kelincahan

Kelincahan adalah yang berhubungan dengan kemampuan dengan cara mengubah arah posisi tubuh dengan kecepatan dan ketepatan tinggi.

e. Koordinasi

Koordinasi adalah yang berhubungan dengan kemampuan untuk menggunakan panca indra secara bersama sama dengan tubuh tertentu didalam melakukakan kegiatan motorik.

f. Kecepatan reaksi

Kecepatan reaksi adalah yang berhubungan dengan kecepatan waktu yang dipergunaka antara mulai adanya simulasi atau ransangan dengan mulainya reaksi.

3. Kesegaran jasmani yang berhubungan dengan Wellness

Sebagai suatu tingkat dinamis dan terintegrasi dari fungsi-fungsi organ tubuh yang berorientasi terhadap upaya memaksimalkan potensi yang memiliki ketergantungan pada tanggung jawab diri sendiri (Harsuki, 2003:274).

\section{B. METODOLOGI PENELITIAN}

Jenis penelitian ini termasuk Eksperimen Semu (quasi eksperimen). Variabel bebas dalam penelitian ini adalah SKJ 2012, Variabel terikatnya adalah Kebugaran Jasmani siswa SMPN 35 Palembang.

Populasi penelitian ini adalah semua siswa kelas VIII SMP Negeri 35 Palembang berjumlah 135 orang. Teknik pengambilan sampel dalam penelitian ini adalah menggunakan teknik Purposive Sampling yaitu penentuan sampel berdasarkan pertimbangan tertentu dari peneliti. Berdasarkan hal tersebut, maka peneliti mengambil siswa putra. Jumlah sampel dalam penelitian ini adalah 70 orang. 
Dari 70 siswa putra yang dijadikan sampel, maka Sebelum perlakuan (treatment) dilaksanakan, terlebih dahulu diberikan pretest kepada sampel. Setelah pretest maka sampel dibagi menjadi dua kelompok masing-masing 35 orang dengan cara ordinary matched pairing agar kedua sampel ini tergolong homogen. Selanjutnya dilakukan undian untuk menentukan kelompok mana yang diberikan perlakuan menggunakan latihan SKJ 2012 dan kelompok yang tidak diberi perlakuan sebagai kelompok kontrol.

Data yang terkumpul dari hasil pre-test, post-test dianalisis dengan menggunakan statistik pada uji normalitas dan uji-t. Uji normalitas dengan menggunakan Lilliefors, bertujuan untuk mengetahui data yang diperoleh apakah berdistribusi normal atau tidak. Kemudian dilanjutkan dengan Uji Homogenitas varians, untuk melihat apakah data berada dalam homogen apa tidak selanjutnya dianalisis menggunakan rumus Uji-t.

\section{HASIL DAN PEMBAHASAN}

Berdasarkan hasil perhitungan uji normalitas, kelompok rancangan penelitian ditemukan bahwa harga $L_{\text {obesrvasi }}\left(L_{0}\right)$ yang diperoleh lebih kecil dari harga $L_{\text {tabel }}$ pada taraf nyata 0,05. Dengan demikian dapat disimpulkan bahwa semua kelompok data pada penelitian ini diambil dari populasi yang berdistribusi normal.

Kemudian dilanjutkan berdasarkan hasil perhitungan uji homogenitas, Hasil analisis di atas terlihat bahwa nilai $\mathrm{F}_{\text {hitung }}$ adalah 1,006 sedangkan $\mathrm{F}$ tabel dengan menggunakan derajat kebebasan (n1-1), (n2-1) dan dengan taraf signifikansi probability pada setiap variabel lebih besar dari 0,05, jadi didapat $F_{\text {tabel }}=2,45$ dengan demikian berarti bahwa data penelitian ini adalah homogen, ini dikarenakan 1,006 < 2,45. sehingga dapat dilanjutkan untuk analisis pengujian hipotesis.Berdasarkan rangkuman hasil perhitungan normalitas dan homogenitas maka hipotesis dapat dikemukakan bahwa: 
Pengaruh Latihan SKJ 2012 terhadap Kebugaran....(Arisman)

Berdasarkan data yang di peroleh $t_{\text {hitung }}(13,85)>t_{\text {tabel }}(1,676)$. Hal ini berarti bahwa hipotesis penelitian dapat diterima. Dengan demikian dapat diartikan bahwa SKJ 2012 memberikan pengaruh yang signifikan terhadap tingkat kebugaran jasmani siswa SMP 35 palembang.

Hasil penelitian membuktikan bahwa terdapat pengaruh SKJ 2012 terhadap tingkat kebugaran jasmani siswa SMP 35 palembang. Sebelum diberikan perlakuan terhadap sampel terlebih dahulu dilakukan tes awal. Berdasarkan hasil tes tersebut diperoleh tingkat kebugaran jasmani siswa dengan mean (rata-rata) pada saat pre tes yaitu sebesar 12,90, namun setelah diberikan perlakuan dengan latihan SKJ 2012 sehingga terjadi peningkatan kebugaran jasmani dengan mean (rata-rata) menjadi 14,98. Dengan hasil penelitian tersebut dapat disimpulkan bahwa terdapat pengaruh latihan SKJ 2012 terhadap kebugaran jasmani siswa SMP 35 palembang, hal tersebut juga diperkuat setelah dilakukan dengan uji t, dimana diperoleh hasil $\mathrm{t}$ hitung sebesar 13,85 yang lebih besar dari $\mathrm{t}$ tabel dalam taraf $\alpha=0.05$ sebesar 1.676 .

Untuk dapat meningkatkan kebugaran jasmani salah satu bentuk latihan yang dilakukan yaitu dengan latihan SKJ 2012. Oleh karena itu, hal ini dapat menjadi masukan bagi para guru untuk dapat memilih dan menjadikan SKJ 2012 sebagai bentuk latihan dalam meningkatkan kebugaran jasmani siswa di sekolah.

\section{SIMPULAN}

Berdasarkan analisis data dan pembahasan yang telah dijelaskan sebelumnya, maka dapat dikemukakan kesimpulan Sebagai berikut:

Pemberian SKJ 2012 berpengaruh signifikan terhadap peningkatan kebugaran Jasmani Siswa SMP Negeri 35 Palembang.

Berdasarkan kesimpulan di atas, maka diajukan beberapa saran, antara lain :

1. Senam ini dapat digerakan pada seluruh siswa sekolah sebagai kegiatan rutin dalam upaya meningkatkan kebugaran jasmani siswa. 
2. Bagi pembaca semoga menambah pengetahuannya mengenai senam bagi kebugaran jasmani.

3. Bagi peneliti lain diharapkan agar dapat kiranya mengembangkan penelitian ini lebih baik lagi terhadap tingkat kebugaran jasmani dengan cara yang lain agar mendapatkan hasil yang maksimal.

4. Penelitian ini terbatas pada siswa laki-laki saja, oleh sebab itu bagi peneliti selanjutnya agar dapat mengembangkan penelitian ini pada sampel yang lain serta dengan jumlah yang lebih banyak.

\section{DAFTAR PUSTAKA}

Brick, Lynne. 2001. Bugar Dengan Senam Aerobik. Jakarta: PT Raja Grafindo Persada.

Harsuki. 2003. Perkembangan Olahraga Terkini. Jakarta: PT Raja Grafindo Persada.

Hermansah, Bambang. 2018. Modifikasi Permainan Bola Tangan terhadap Hasil Belajar Passing dalam Pembelajaran Bola Tangan Mahasiswa. Wahana Didaktika : Jurnal Ilmu Kependidikan (Online). Volume 16 Nomor 1:35-41. FKIP Universitas PGRI Palembang.

Margono, Agus. 2009. Senam. Surakarta: UNS Press.

UU RI. No.3. 2005. Sistem Keolahragaan Nasional. Bandung: Citra Umbara.

Wiarto, Giri. 2015. Panduan Berolahraga Untuk Kesehatan dan Kebugaran. Yogyakarta: Graha Ilmu. 